\title{
Roads Less Traveled: Emerging Tourism in Peru
}

\author{
by
}

\author{
Jeffrey S. Smith and Douglas A. Hurt
}

Peru is one of the world's most biologically rich and geographically diverse countries. According to the United Nations Environment Programme (UNEP), it is also classified as one of the world's seventeen megadiverse countries. Peru is comprised of three major physiographic regions including the Coastal Lowlands, Andean Highlands, and the Amazon Basin (Figure 1). It is home to over 50,000 plant and animal species including more than 3,500 different types of butterflies, and over 1,750 species of birds (Ugarte and Pacheco 2001, Blacker 2008). Peru's 60 national parks and nature preserves ensure that the country's unique biodiversity will be protected for generations to come. All of this is remarkable given that Peru is only one-seventh the size of the U.S. (Figure 2).

Peru's population distribution is as distinctly divided as its three physiographic regions. With the exception of

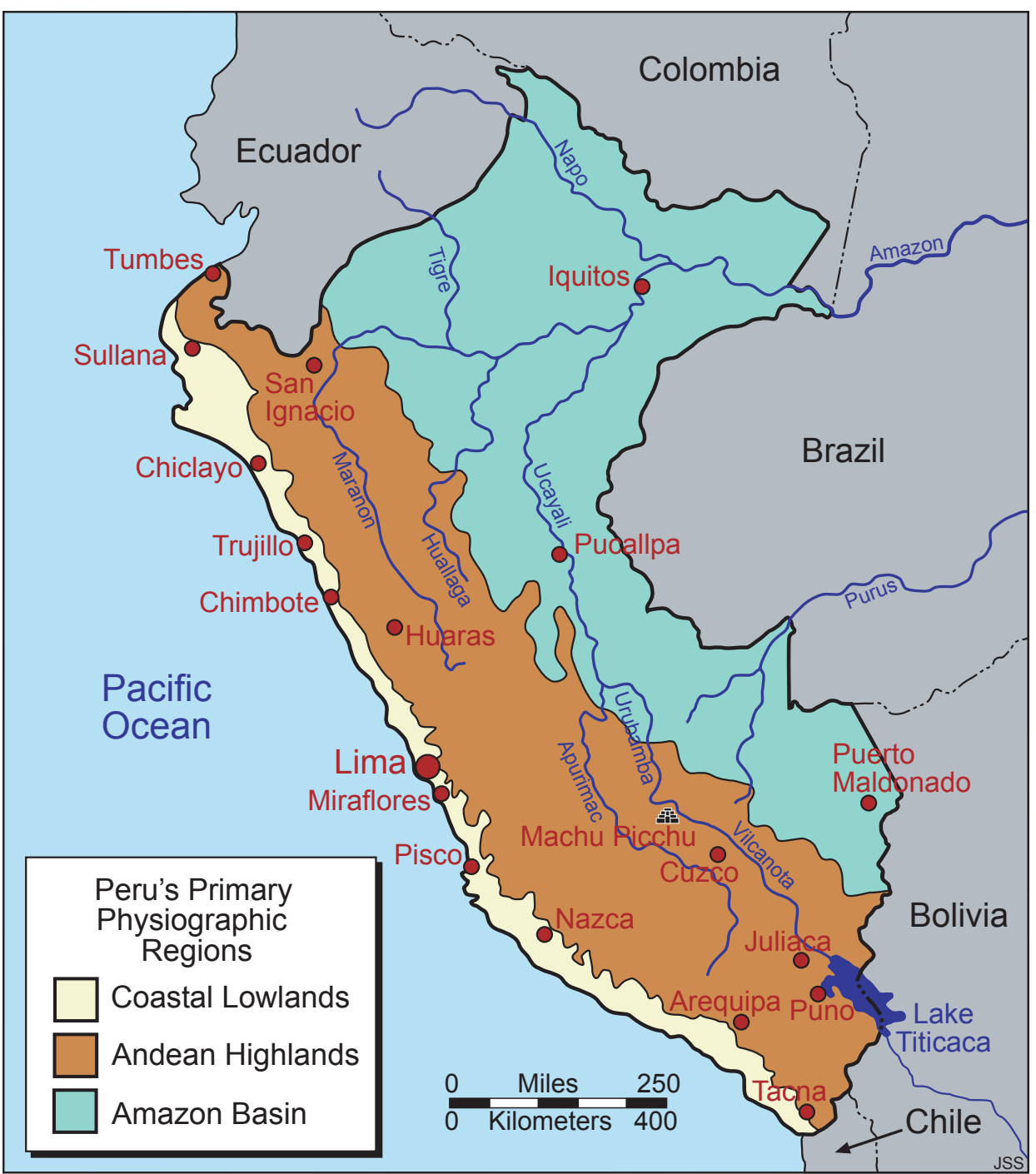

Figure 1: Map of Peru highlighting the three major physiographic regions. (Cartography by Jeffrey Smith)
Arequipa and Cuzco, whose populations fill high Andean valleys, the majority of Peru's urban centers (including Lima, Trujillo, and Chiclayo) lie within the fairly narrow coastal region (Figure 1). Here the stark contrast between the affluent mestizos and the poorer indigenous populations is most striking. Surrounding the sprawling urbanized centers are hillsides of informal settlements that serve as testament to the waves of people who have fled the rural, highland areas over the past three decades.

With over $60 \%$ of the country's rural dwellers, the mountainous region (Figure 1) is dominated by people of indigenous background including Quechua, Aymara, and Q'eros groups. Most of Peru's native population survives by scratching out a living through subsistence agriculture, yet the adverse affects of abject poverty take their toll.

Although Peru's Amazon Basin (Figure 1) covers over one-half of the country's land mass and is flavored with more than 50 linguistic groups, the area is home to only about five percent of Peru's total population (Blacker 2008). The Amazon Basin is the most neglected

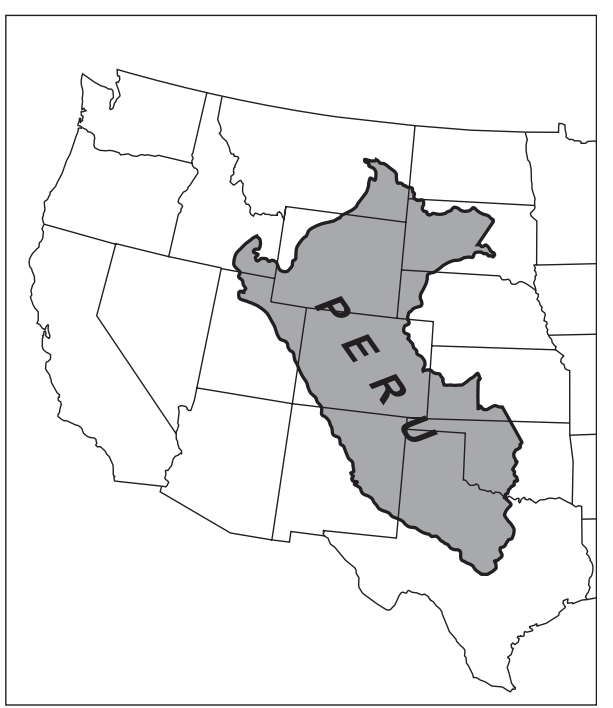

Figure 2: Map showing the size of Peru relative to the western United States. (Cartography by Jeffrey Smith) 
part of the country; the region lacks even the most basic infrastructure and services.

Despite being a land of remarkable contrasts, most of Peru's international visitors spend the majority of their time in only three locations: Lima, Cuzco, and Machu Picchu (O'Hare and Barrett 1999). Lima contains the country's only intercontinental airport so a vast majority of foreign tourists enter the country through the capital city. South America's oldest city offers handsome architecture, picturesque plazas, as well as numerous museums and archaeological sites that house rich pre-
Columbian and colonial artifacts. The San Francisco Convent with its overflowing shelves of 17th Century books and maps is popular among scholars of every ilk. Most international visitors, however, spend little more than a couple of days exploring Peru's largest city. Instead they fly to the country's widely acclaimed and most famous international tourist destinations: Cuzco and Machu Picchu.

Serving as the primary gateway to Peru's highland region, Cuzco has been labeled the "archaeological capital of the Americas" and the "navel of the world."
The city is located at 11,380 feet above sealevel and many tourists who fly from Lima (at sea level) to the ancient Incan capital experience "altitude sickness." Wise visitors ensure a flexible itinerary upon arriving in Cuzco to let their body acclimate. A quick fix remedy for mild cases is to drink a cup of ever-present coca tea. Cuzco is widely popular for its juxtaposition of rich Incan and colonial architecture, abundant native population, and magnificent ancient ruins (Figures 3). Of particular note is the Incan fortress of Sacsayhuamán (pronounced "sexy-woman"). This site,

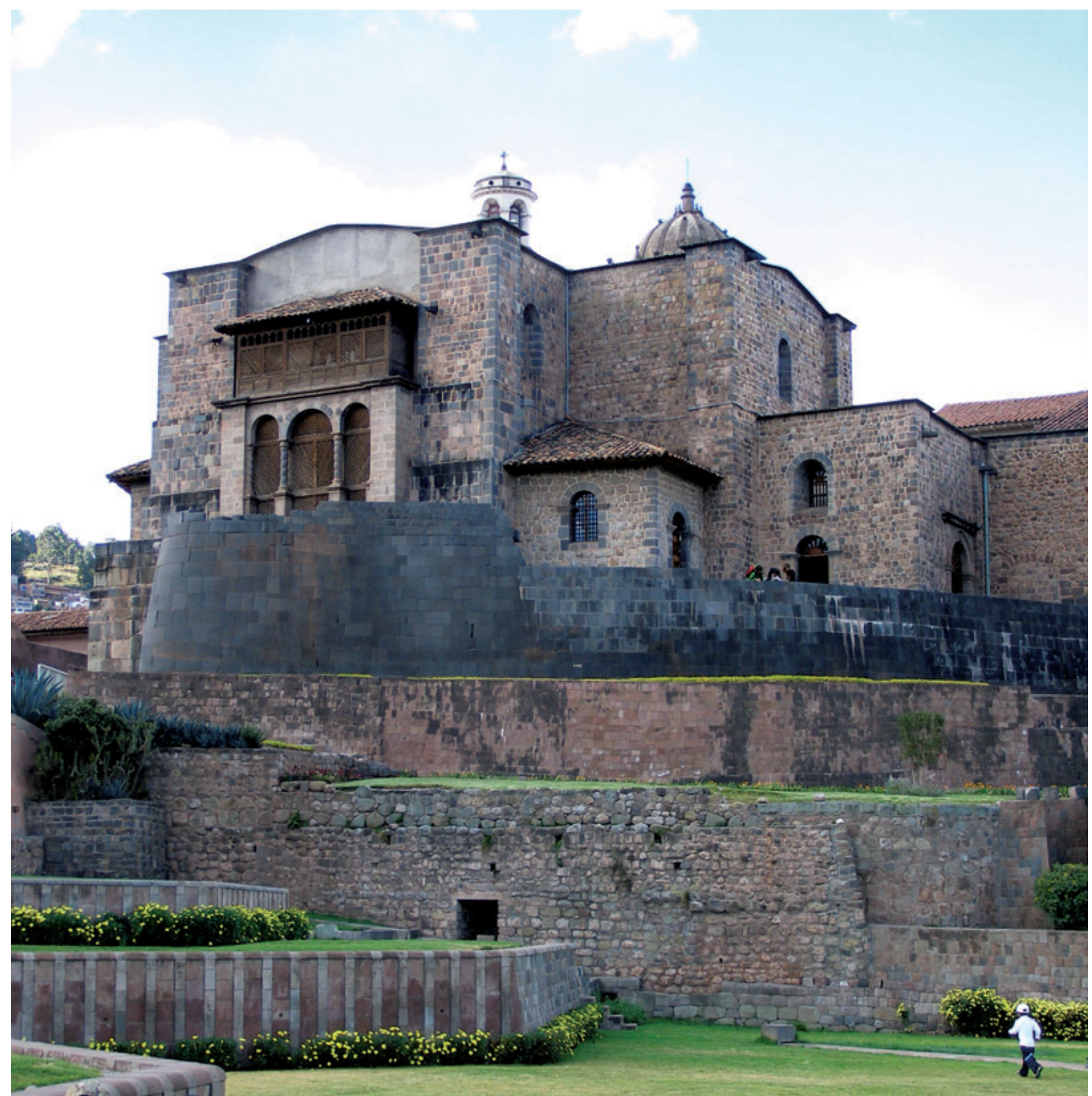

Figure 3: Santo Domingo Convent and Cathedral in Cuzco. The Spanish colonial structure was built on top of the Incan Temple of the Sun. (Photo by Jeffrey Smith, May 2009) 


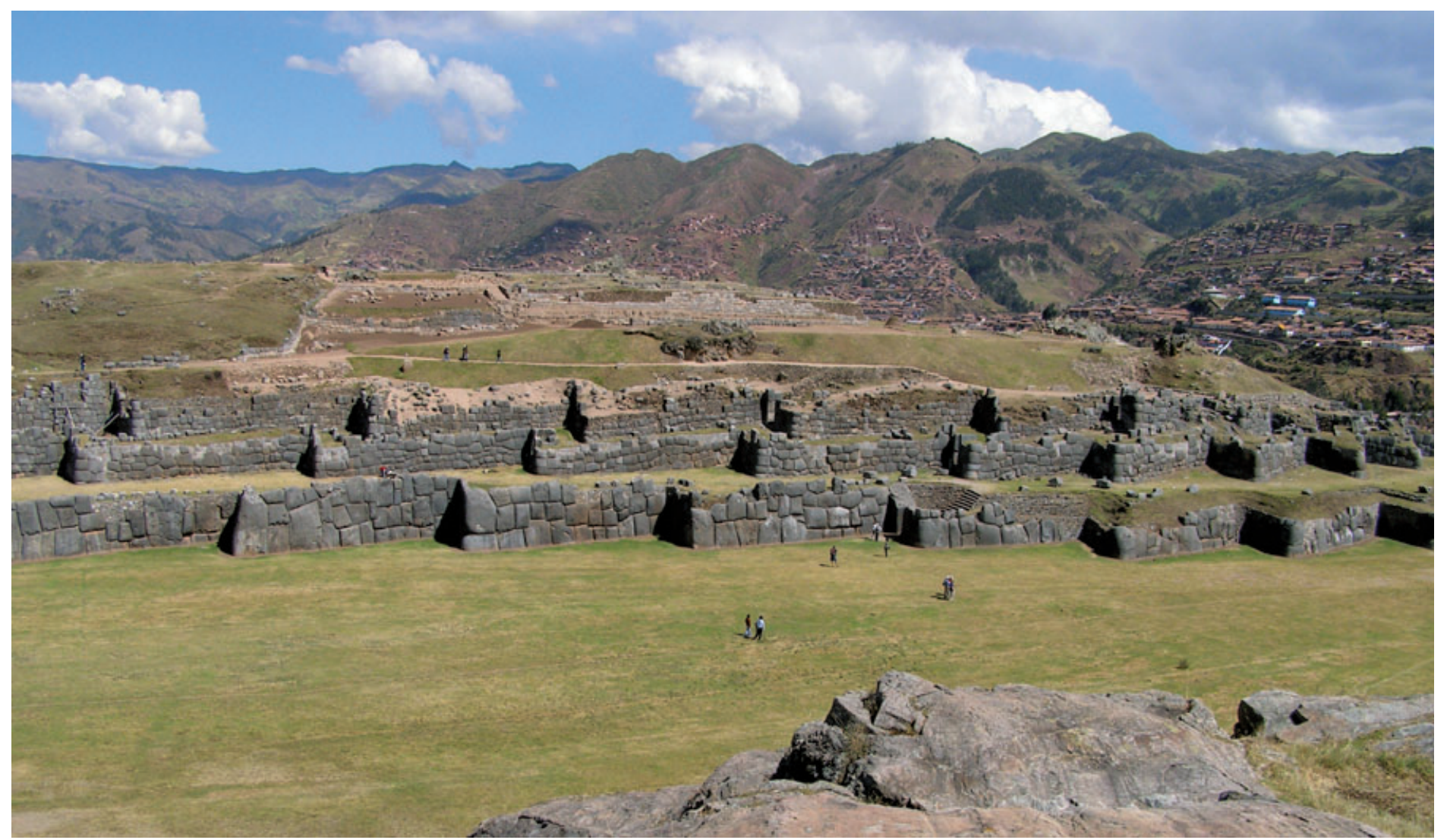

Figure 4: The Incan fortress of Sacsayhuamán as viewed from nearby hill. (Photo by Jeffrey Smith, May 2009)

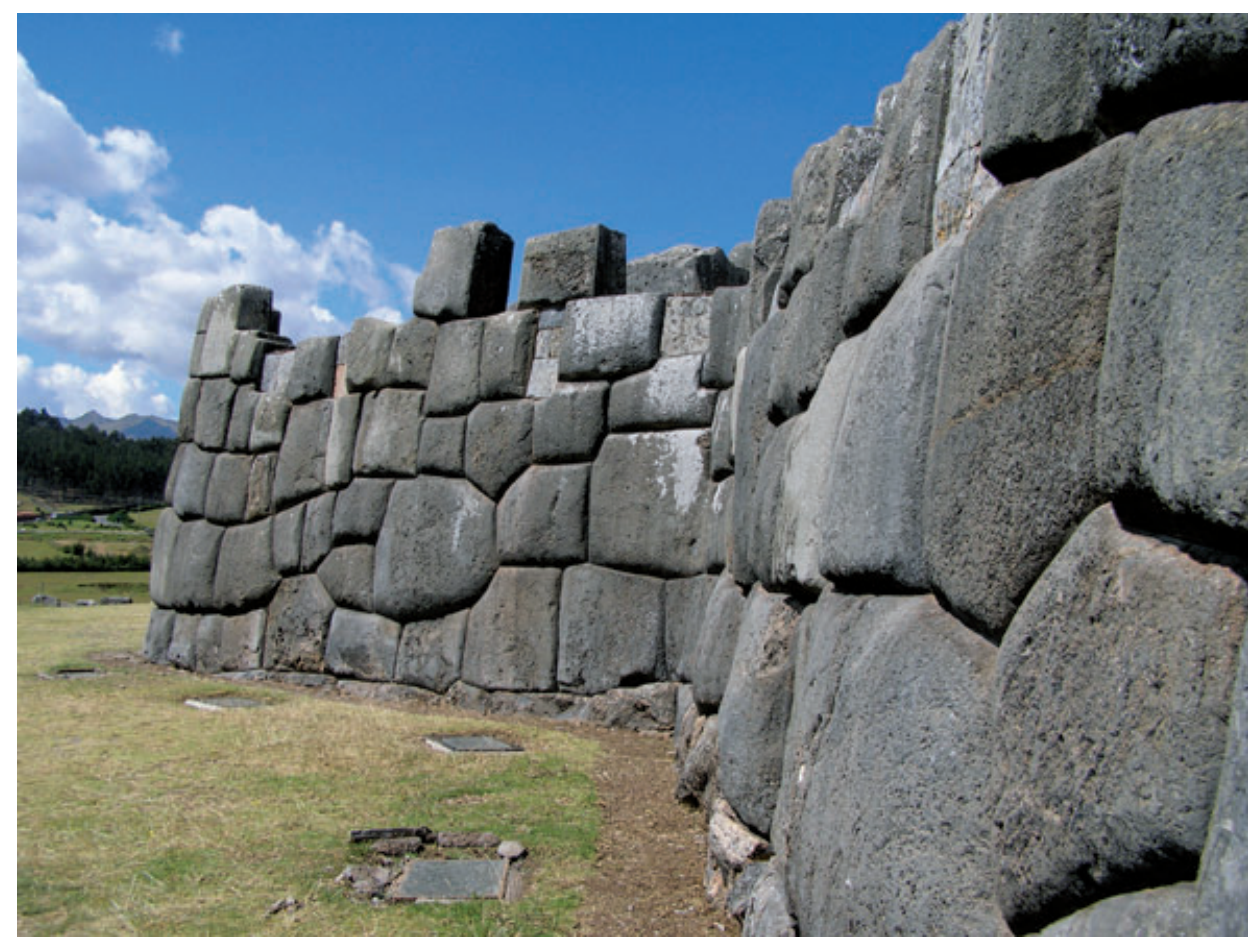

Figure 5: Large rocks pieced together at Sacsayhuamán near Cuzco. (Photo by Douglas A. Hurt, June 2006)

overlooking Cuzco, features some of the largest stones ever faceted together by ancient Incan peones (Figures 4 and 5).

The highlight of most peoples' trip to Peru is time spent at Machu Picchu
(Figure 6). Few of the 68,000 people who visit the ruins in an average month (Economist 2010) are left disappointed because the experience goes far beyond what the plethora of photos on the internet can provide. Images snapped with a camera fail to capture the grandeur and magnificence of the setting. More recently tourists have found that climbing to the top of Waynapicchu Mountain on the northwest side of the ruins offers them an unique perspective of Machu Picchu; one worthy of the harrowing and arduous hike. Given the steep topography, local guides recommend allowing at least four hours for the round trip hike from the ruins of Machu Picchu to the top of Waynapicchu. Furthermore, only 400 people are permitted on the trail at the same time. Both Cuzco and Machu Picchu are among Peru's eleven UNESCO World Heritage sites. If any of the nearly one million international tourists who visit Peru annually (Blacker 2008; Divino and McAleer 2009) do not visit Cuzco and Machu Picchu it would be an egregious error.

With that said, however, an UNESCO sponsored report has strongly encouraged the Peruvian government to limit the total number of visitors in Machu Picchu each day to 917 people and only 385 at any one time. By comparison, Peru's National Institute of Culture (INC) has established a maximum carrying capacity of 2,000 people. On multiple occasions UNESCO has threatened to withdraw its affiliation if Peru does not ensure the cultural and 


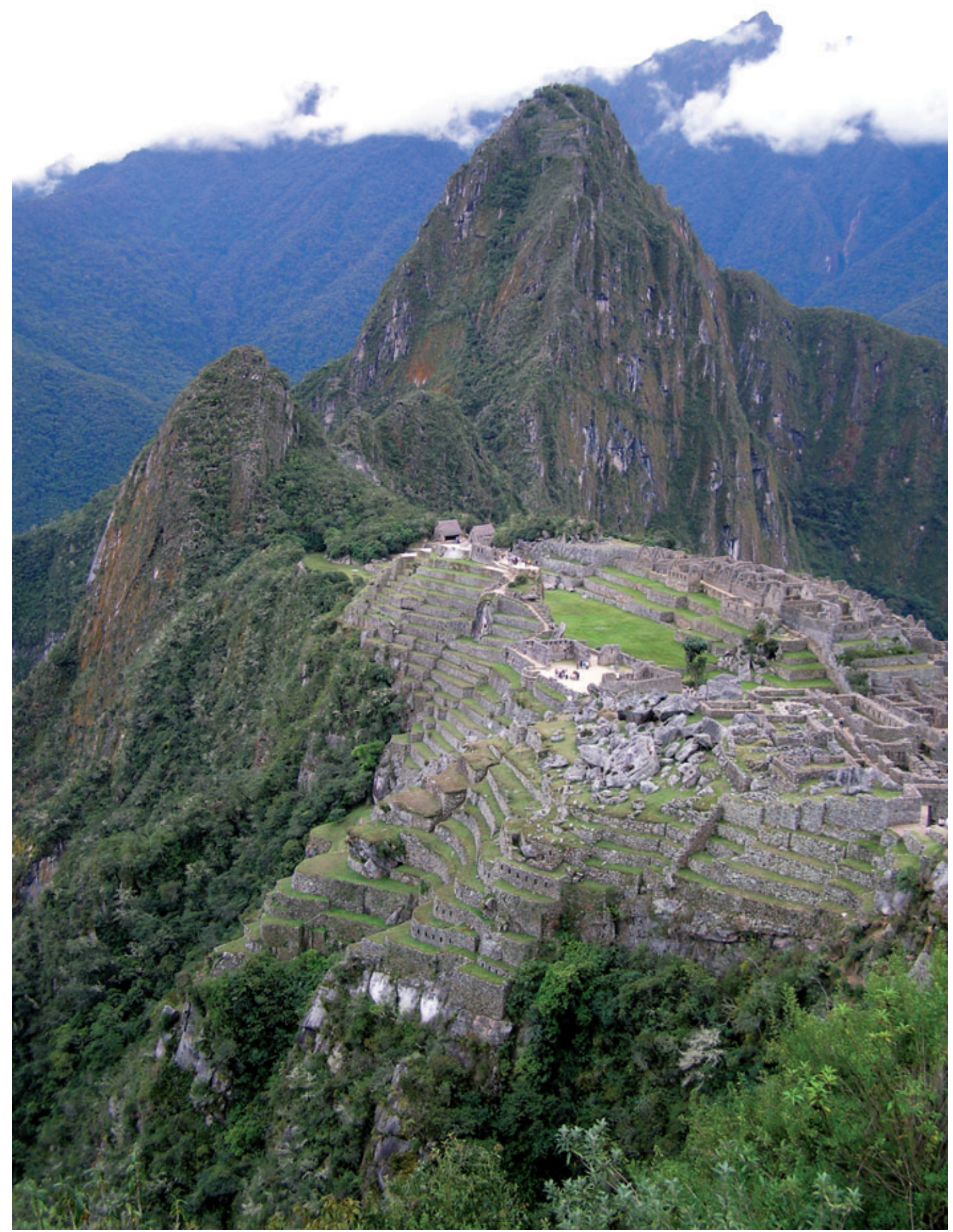

Figure 6: Machu Picchu with Waynapicchu mountain in the background. Waynapicchu mountain provides the backdrop for most photos of Machu Picchu. The Spanish originally spelled the mountain "Huayna Picchu." (Photo by Jeffrey Smith, May 2009)

environmental sustainability of the site (UNEP 2008; Vecchio 2010).

Because of the growing concerns over how concentrated tourism is within the country (Economist 2010; Vecchio 2010), officials in Peru's Ministry of Tourism and International Trade are spending consider- able resources marketing some of Peru's other attractive and unique destinations including the Nazca Lines and the coast near Trujillo. Despite the government's best efforts, international tourists have been reluctant to venture off the wellbeaten path. In February 2010, Peru's vulnerability to concentrated tourism was exposed when torrential rains produced major mudslides in the region around Machu Picchu. Not only did the debris flows destroy eight sections of the railroad, but approximately 3,900 tourists were stranded in the gateway community of 
Aguas Calientes (also called Machu Picchu Pueblo). Because the railroad provides the only transportation route in and out of the area, the Peruvian government was forced to evacuate visitors via helicopters (some of which were borrowed from Brazil). Once the tourists were safely removed, the Peruvian government scrambled to repair the railroad tracks as quickly as possible so that tourism to the nation's premier destination could resume. One estimate suggested that 15,000 people were left unemployed and the country was losing at least one million dollars in tourism revenue each day the railroad line was not functioning (Economist 2010).

In light of this catastrophic event, the Peruvian government is redoubling its efforts to promote tourism in other parts of the country. Many places with equally rich cultural sites and spectacular scenery are poised for a boom in tourism. The purpose of this article is to showcase three of Peru's emerging tourist destinations including the Sacred Valley, the Colca Canyon, and the northwest shore of Lake Titicaca. As the end of the first decade of the 21st Century approaches, international tourism has yet to make a sizeable impact on the local economy in these three locations. We contend, however, that the foundation for tourism growth is being poured and it may be only a matter of time before international visitors descend upon these places in force.

Information for this article was derived from two separate excursions to Peru. Although our primary intent was to spend time seeing the country's internationally acclaimed tourist destinations in Lima, Cuzco, and Machu Picchu, our guides introduced us to some of Peru's emerging and developing tourist attractions. Furthermore, we were given the opportunity to more fully explore places not on our original itineraries because our travel plans were disrupted due to Peru's ever-common strikes and protests (Figure 7). We garnered information from a wide variety of people including guides, tourism officials, business owners, and a variety of local residents. This article is a compilation of our findings stemming from those frustrating, yet serendipitous, moments.

\section{The Sacred Valley}

Located approximately 30 kilometers (18 miles) from Cuzco, but taking more than one hour to reach by vehicle, the Sacred Valley straddles the VilcanotaUrubamba River in the heart of the Cuzco Knot of the Andes Mountains (Figure 8 -

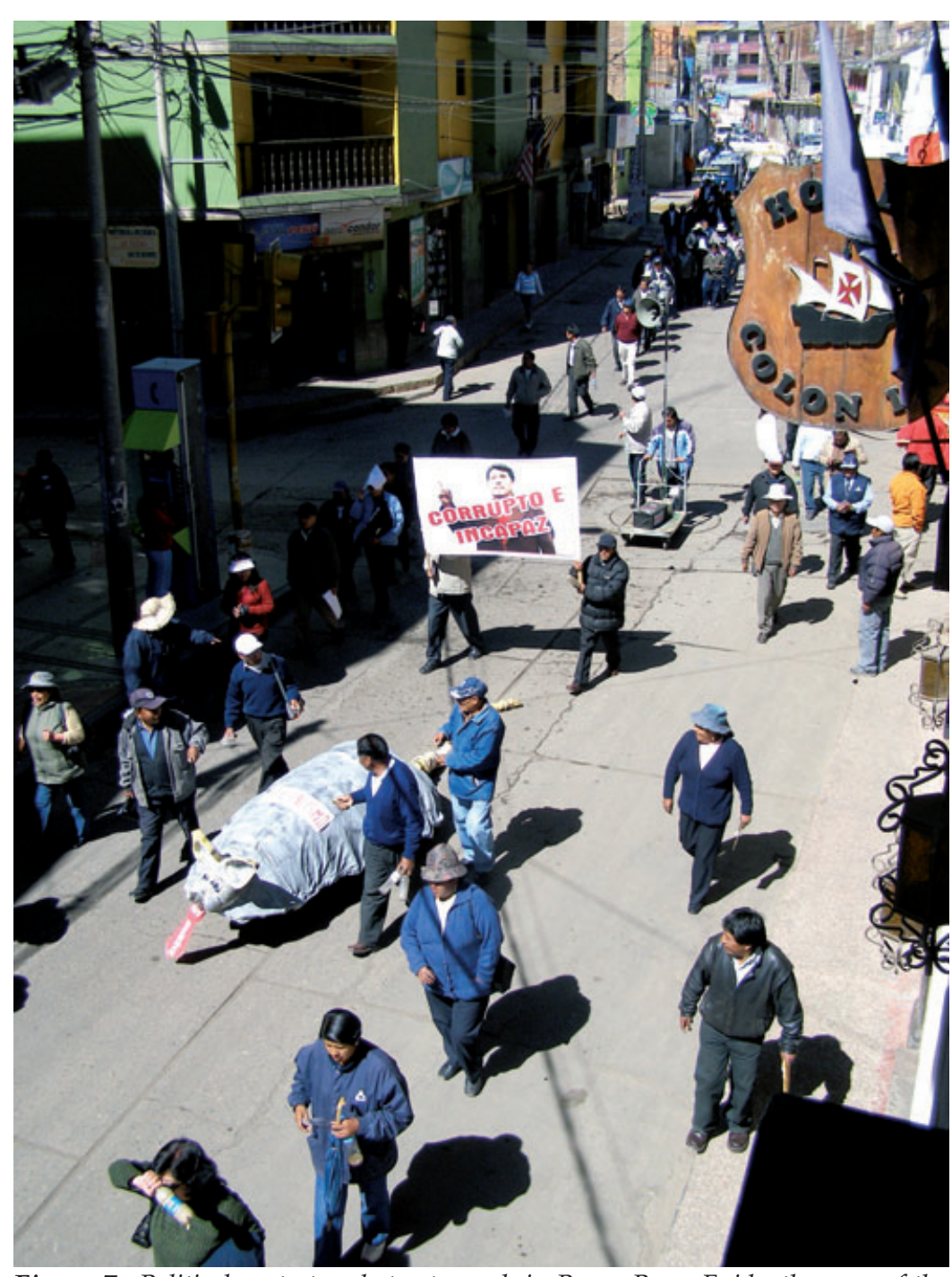

Figure 7: Political protest and street march in Puno, Peru. Evidently some of the local residents think one governmental official is a rat. (Photo by Jeffrey Smith, May 2009)

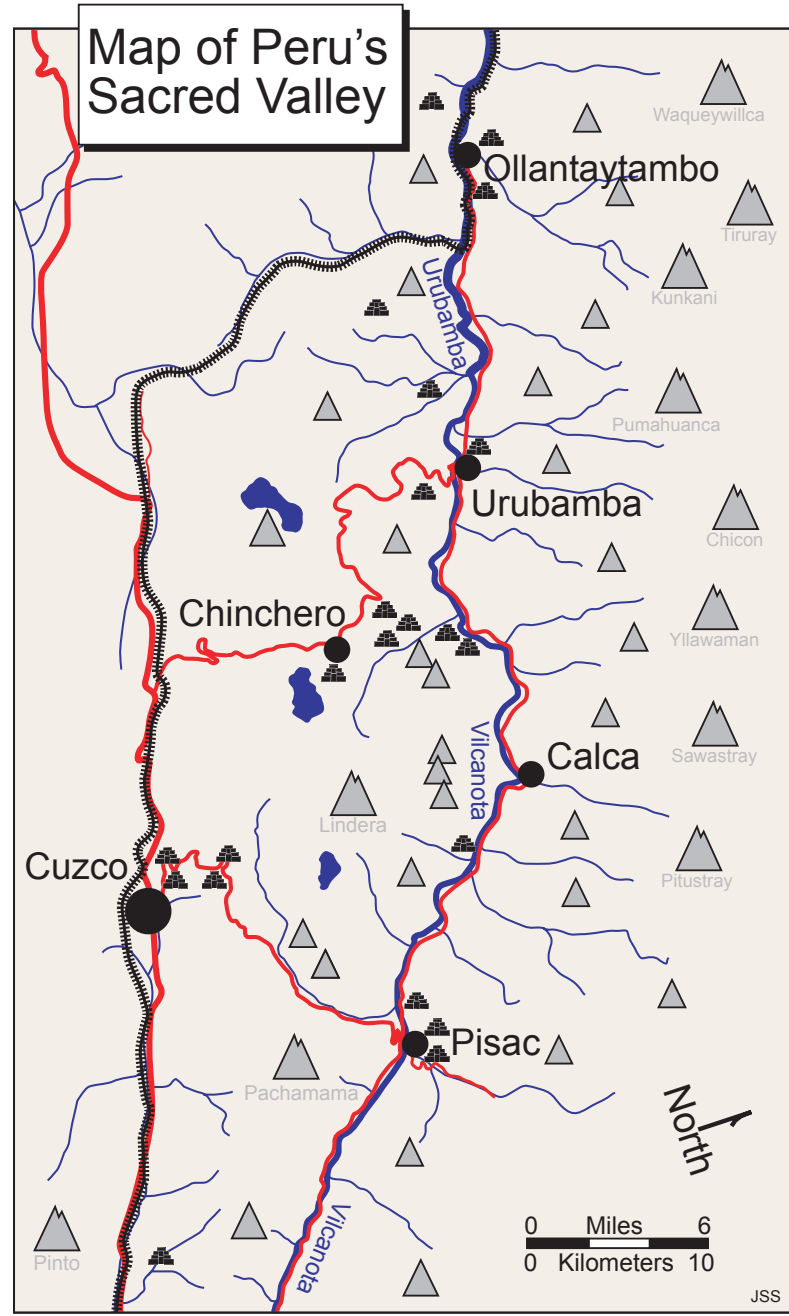

Source: Adapted from delange.org and LatinDiscover.com

Figure 8: Map of Cuzco and Sacred Valley. Peru has over 50 peaks that reach elevations of at least 5,600 meters ( 18,500 feet). The Cuzco Knot contains no less than eleven of these, all of which can be seen from the Sacred Valley. (Cartography by Jeffrey Smith) 
map of Sacred Valley). The narrow, "V-shaped" valley extends nearly 75 kilometers (45 miles) from just east of Pisac to Ollantaytambo in the west (Figure 9). Most of the river's energy has been spent down-cutting thus enhancing the area's steep slope gradient. At various locations along the narrow valley the local topography flattens out allowing the river to meander and flow more smoothly. Along these stretches the valley hosts rich agricultural lands where crops (especially maize) are grown and livestock (especially sheep, llama, and alpaca) are raised. In many of these same locations substantial tributaries flow out of the surrounding foothills and intersect with the Urubamba River. Here rock and dirt laden debris is distributed as alluvial fans.

Most of the population centers in the Sacred Valley have been established at the juncture of the flood plain and the alluvial fans. The town of Pisac (commonly referred to by locals as the last remaining truly Incan settlement) is a classic example. The village simulta-

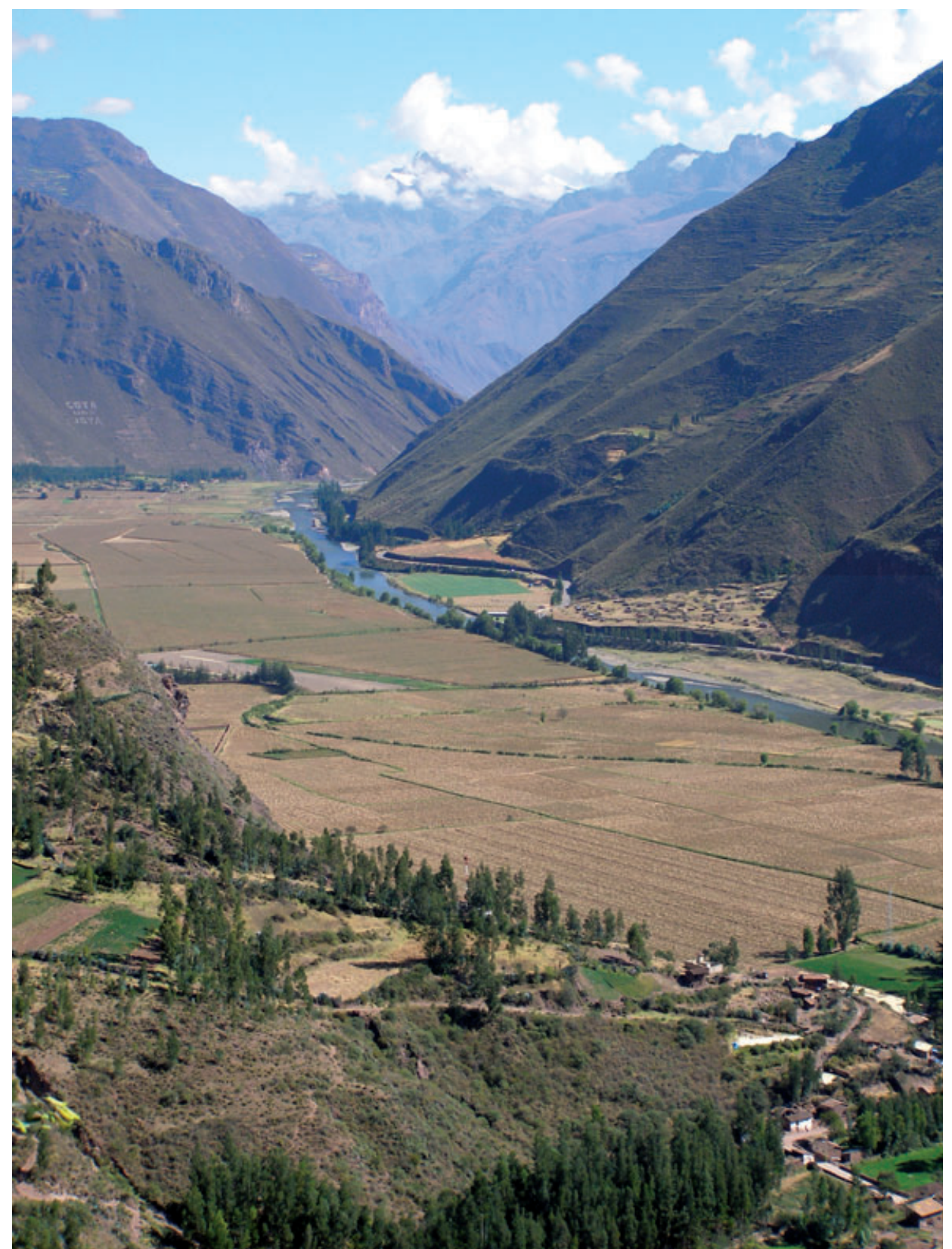

Figure 9: The V-Shaped Sacred Valley near Pisac. Our guides declared that the Inca nobility named the valley "Yucay" (Sacred Valley) because of its fertile soil, appealing climate, and abundant flora and fauna. A local legend asserts that because corn plants in this valley have larger kernels than anywhere else in the known world, the Gods must hold this valley in particular favor and therefore it must be sacred. (Photo by Jeffrey Smith, May 2009)

neously sits on the upper margin of the floodplain and on the lower slope of an alluvial fan (Figure 10). The local population has built their towns on this transitional ground thereby preserving most of the prime agriculture land for growing foodstuffs and avoiding inundation during periodic flooding.

There are two viable paved roads that connect Cuzco and Ollantaytambo (the place where most tourists board PeruRail as they head to Aguas Calientes) (Figure 8). Most tour companies, however, escort international visitors on the high road through the town of Chinchero because the route and commute times are much shorter. Significantly fewer tourists arrive at Ollantaytambo via the Sacred Valley. Most travelers are so focused on getting to Machu Picchu that they, or their guides, see the Sacred Valley as little more than an attractive obstacle on the way to the famous Incan citadel. Those foreign visitors who choose to travel at a more leisurely pace to Ollantaytambo are richly rewarded. The scenery in the Sacred Valley is on par with North America's Rocky Mountains and perhaps as majestic and arresting in relief as the European Alps. Furthermore, this alternative route offers opportunities to visit spectacular archaeological sites without the crowds or expensive entrance fees.

The majestic peaks of the Andes Mountains provide a spectacular backdrop to the Sacred Valley, yet in some cases the viewshed of the highest peaks is obstructed because even the foothills in the area are topographically impressive (Figure 11). Because of this spectacular natural scenery combined with the rich Incan cultural traditions in the area, efforts are being made to make the Sacred Valley a tourist destination in its own right. Information garnered from tourist officials, local guides, business owners as well as published tourist information reveal that the area is being targeted particularly for outdoor recreation enthusiasts.

In recent years one of Peru's increasingly popular tourist attractions among backpackers is to complete the arduous four day trek along the Incan Trail from just west of Ollantaytambo to Machu Picchu. Local entrepreneurs in the Sacred Valley have recognized this tourism potential and are beginning to promote comparable hiking experiences. Instead of sleeping in a tent at night, however, visitors to the Sacred Valley can enjoy all the comforts of a four-star hotel when the day of hiking is done. 


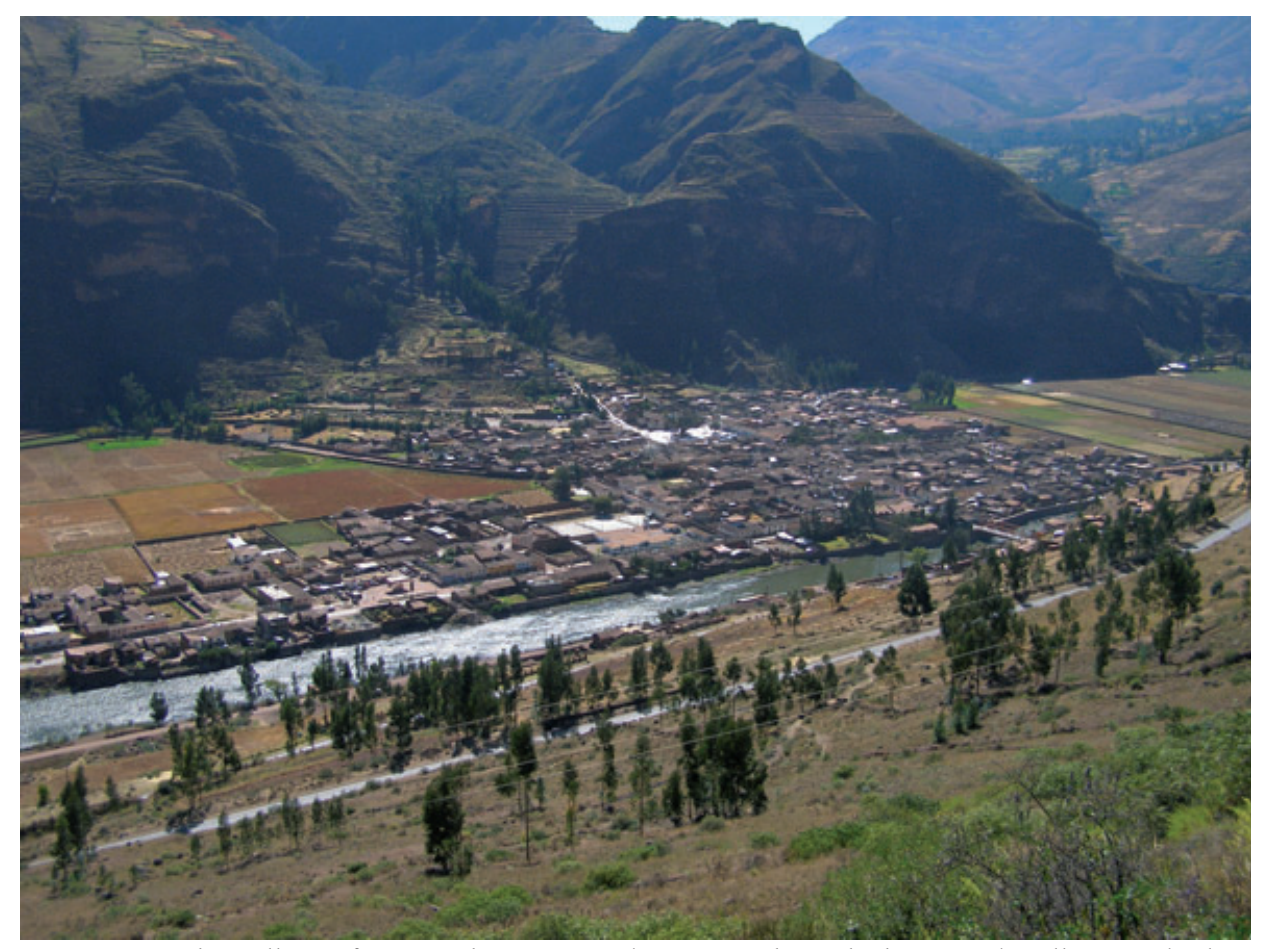

Figure 10: The Village of Pisac. The main road running through the Sacred Valley was built at the base of the alluvial fan where it touches the margin of the flood plain. (Photo by Jeffrey Smith, May 2009)

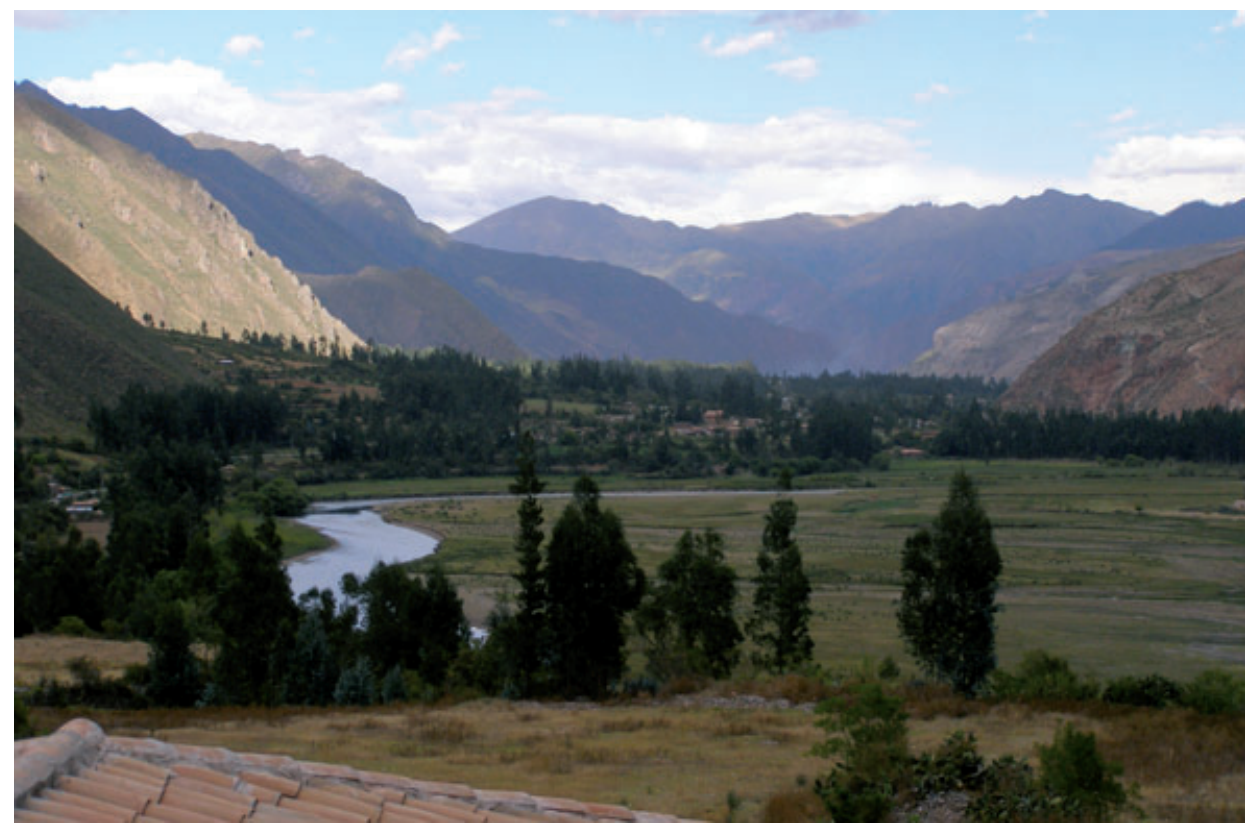

Figure 11: The Sacred Valley with surrounding foothills at a location where the local topography enables the Urubamba River to meander. (Photo by Jeffrey Smith, May 2009)

Along the two-lane road that runs the length of the Sacred Valley one sees the beginnings of other tourist ventures including mountain biking, white water river rafting, kayaking, and horseback riding. Some local business owners are starting to offer shuttle services to tourists interested in biking, riding, or floating from the rounding foothills and let them enjoy the spectacular scenery as they ride back down the hill slope to the valley floor.

In no way would the outdoor recreation opportunities in the Sacred Valley be mistaken for those available in mountainous regions of western North America, Europe, or New Zealand, but slowly the supportive infrastructure is improving. Local promoters see the potential for tourism growth and are already beginning to diversify. For example, tourist information touts the beginning of infrastructure development in such areas as hang gliding, ballooning, rock climbing, and rappelling.

The biggest challenge to tourist development is the lack of support services. Although there is an adequate and increasing number of restaurants (especially Chicago-style pizzerias), there is a noticeable dearth of local hotels, inns, or bed and breakfast establishments where tourists can stay the night. The only two locations with an adequate number of overnight accommodations are Cuzco and Ollantaytambo. This too is changing. One local investor has recently converted a small Catholic monastery into a modest, charming hotel (Figure 12).

Considering the juxtaposition of spectacular scenery, a plethora of well-kept Incan ruins, and rich cultural traditions, the Sacred Valley shows considerable tourism potential. Once international tourists come to appreciate the Sacred Valley for what it has to offer, and no longer see it as just an obstacle on their way to Machu Picchu, things will change very rapidly. Lagging far behind the Sacred Valley, but also showing considerable tourism potential is the Colca Canyon region.

\section{Colca Canyon Country}

For the increasing number of tourists who venture to Arequipa (Peru's second largest city), a two- or three-day side trip to the Colca Canyon offers a chance to visit one of the deepest canyons in the world-twice as deep as Arizona's Grand Canyon (Ugarte and Pacheco 2001; Peru Tourism Bureau 2010). Because the area is approximately 160 kilometers ( 100 miles) from Arequipa, the isolated nature of the Colca Canyon has, heretofore, placed a damper on tourism. Most international visitors arrive in small groups via van or microbus.

From Arequipa, tourists travel northeastward past desert shrub on a paved, two-lane highway (Figure 13). The pace of 


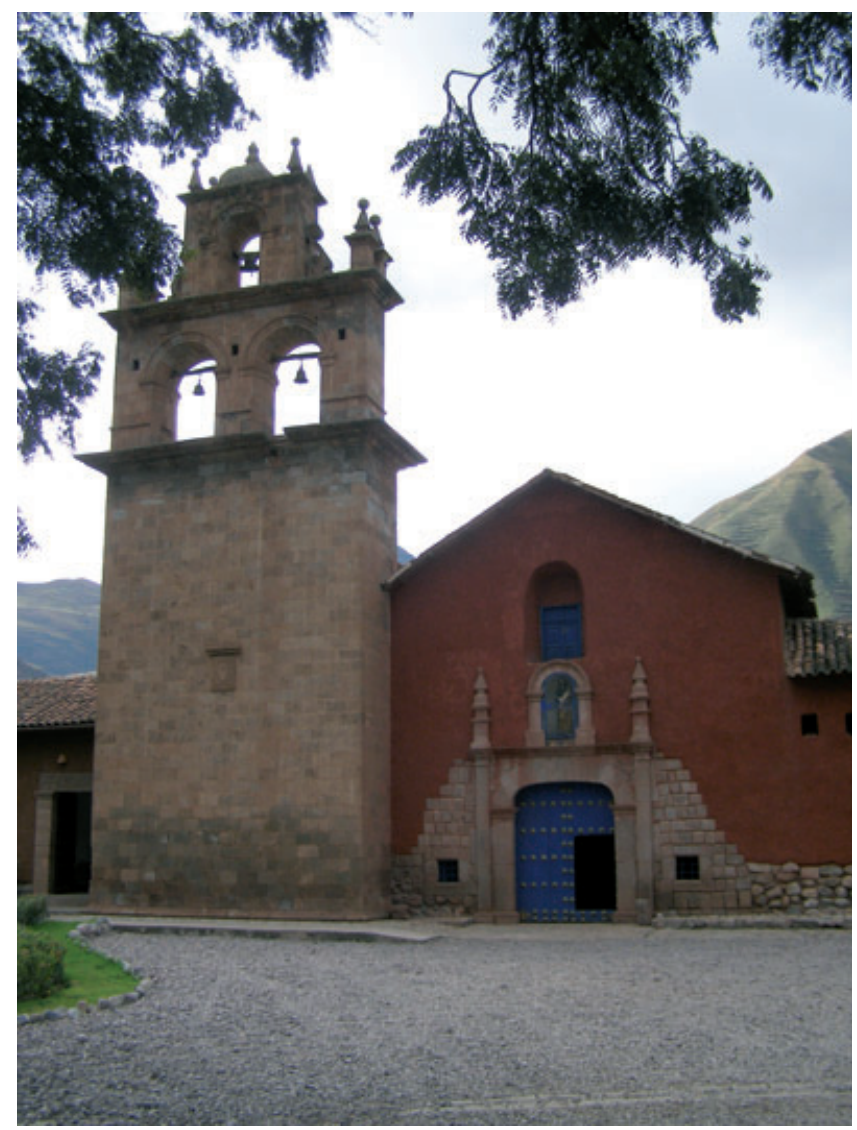

\section{Map of Arequipa and Colca Canyon}

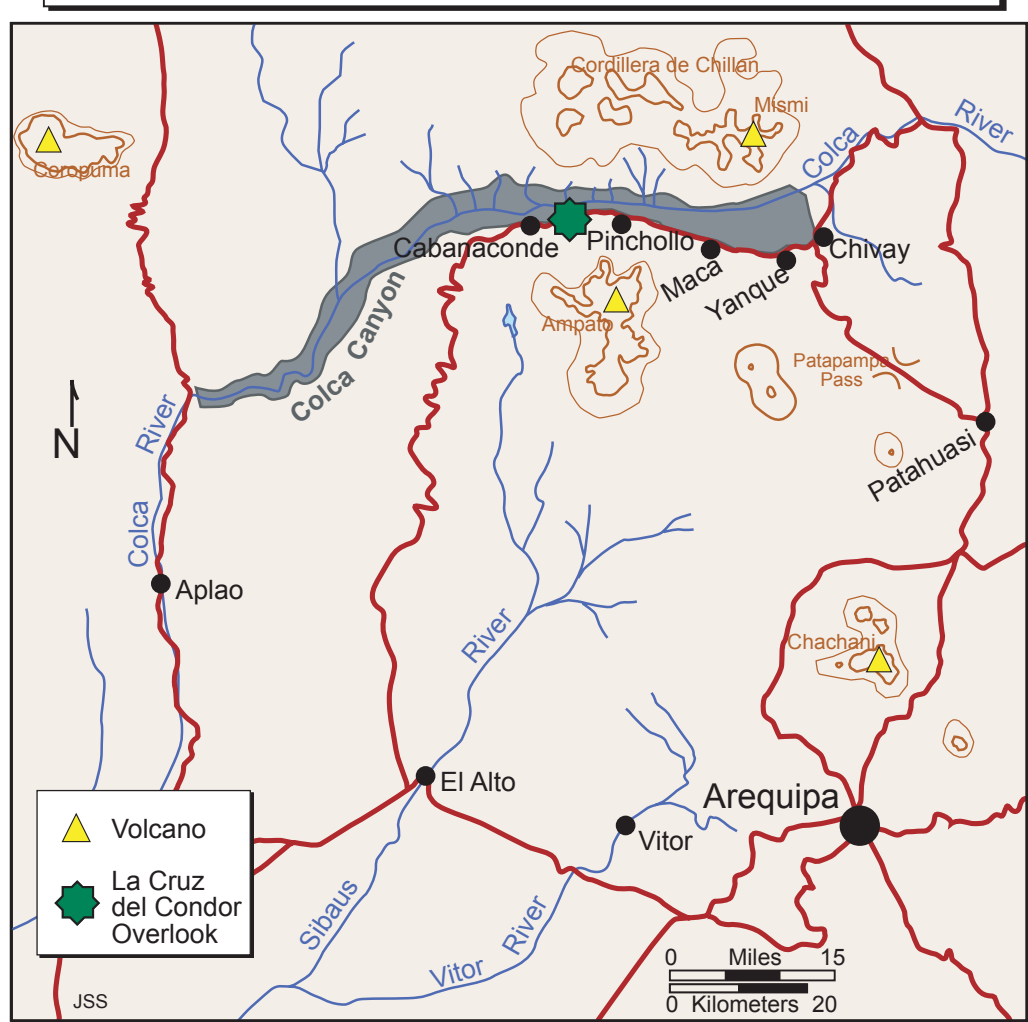

Figure 12: The front of old San Agustin Monastery has been Figure 13: Map of Arequipa and Colca Canyon. (Cartography by Jeffrey Smith) converted to a small hotel. (Photo by Jeffrey Smith, May 2009)

the journey slows considerably at Patahuasi where the vans turn onto a winding road that deteriorates quickly as it makes the long climb in elevation. The slower pace gives travelers a wonderful view of vicunas and llama grazing in the high puna grasslands with distant snow-capped volcanic peaks providing a spectacular backdrop (Figure 14). Apechatas (stone cairn memorials) mark the summit of Patapampa Pass which stands at about 4,900 meters ( 16,000 feet) above sea level. From there the serpentine road quickly descends into the Colca River Valley.

When the Spanish arrived in the region they collectivized the local Collagua Indians into mission settlements. Under this Repartimiento System, the crown could more effectively extract labor from the Indians and convert them to Christianity. Today, most of the resident population lives clustered in fourteen small towns and villages including Chivay, Yanque, Maca, and Pinchollo. At an elevation of approximately 4,000 meters ( 13,000 feet) above sea level, locals are acclimated to the thin air and extreme diurnal temperature changes. Decades of severe population decline and economic stress are evident

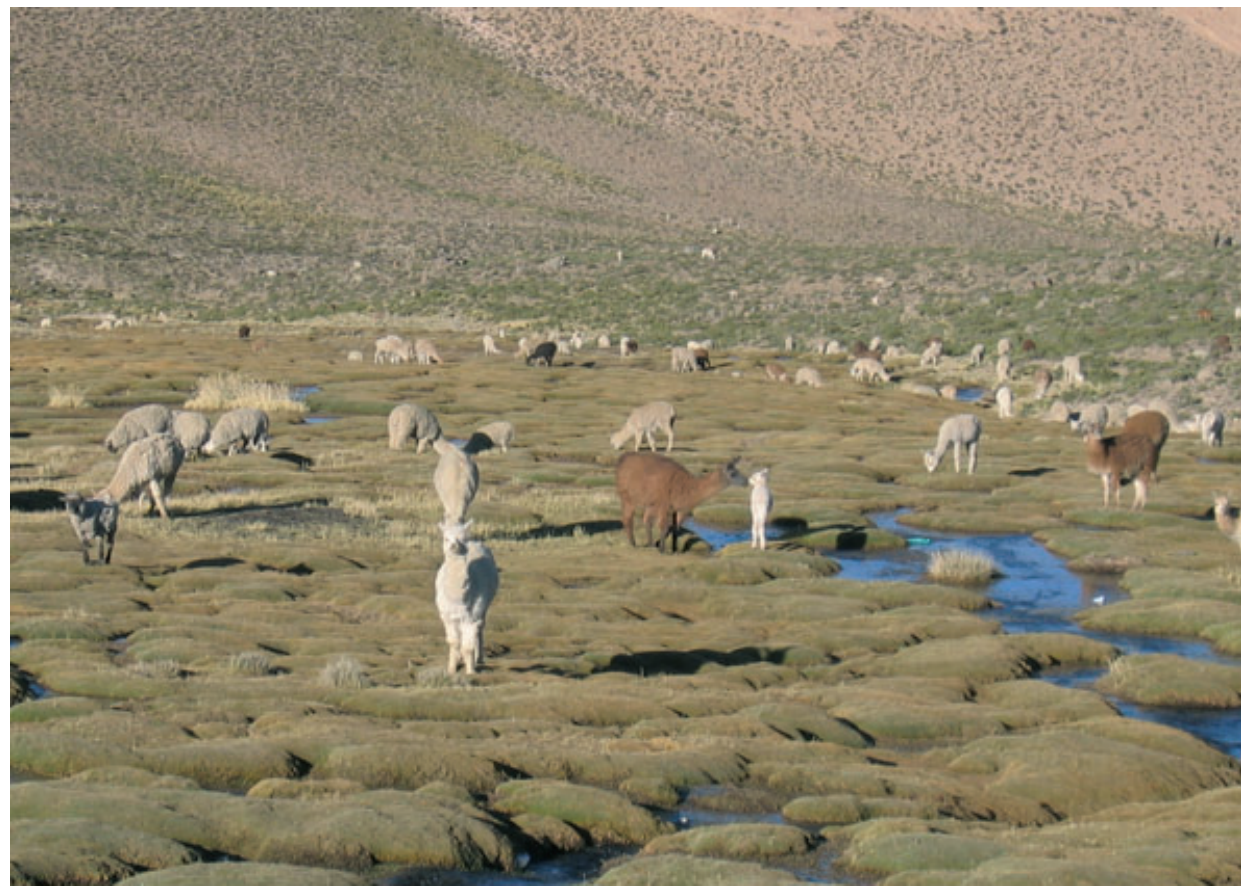

Figure 14: Llamas grazing in a grassland near Vizcachani, Peru. (Photo by Douglas A. Hurt, June 2006)

from the ubiquitous abandoned terraces that are no longer used to grow potatoes, wheat, or corn. Slowly, tourism is adding an important part to the local economy.
Tourist services are dominated by modest motels and hostels although several upscale hotels are available in the valley. The Colca Lodge, for example, was 
built on top of Pre-Incan and Incan terraces and offers spectacular views, fine dining, posh accommodations, and all the services one would expect of a four-star hotel. After spending the day horseback riding, white water rafting, sightseeing, or shopping at the Chivay traditional market, one can relax in the hot springs on the banks of the Colca River or watch the sun set over the picturesque Spanish plazas (Figure 15).

Although time spent exploring the small pueblos of the Colca Valley is enjoyable, most visitors consider the Condor Lookout on the western side of the valley to be the highlight of their trip to the area. The eastern end of the 100 kilometer (62 mile) long Colca Valley is relatively broad and shallow, yet the valley quickly deepens and narrows as one moves westward (Figures 16). East of Cabanaconde, tourists gather early in the morning at La Cruz del Condor (the Cross of the Condor) overlook to watch Andean Condors as they soar on the first thermals of the day. It is common to see six, eight, or even a dozen condors flying at the same time. At this point in the valley, the Colca River is 1,200 meters ( $\sim$ 4,000 feet) below the lookout and the deep gorge provides a dramatic setting to observe the condors (Figures 17). The sizable crowd buzzes with excitement when condors execute flybys only feet overhead. As tourists jockey for a better position to capture photographs and videos, the local guides gruffly move overeager spectators to safer ground away from the rim of the canyon. By mid-morning, the condor flights become rare and many tourists head to an early lunch before returning to Arequipa.

Local guides indicate that visitation to Colca Canyon Country has grown significantly since the 1980s, yet its isolation and underdeveloped infrastructure have limited the number of international visitors who visit the area. It remains to be seen if Peru's Ministry of Tourism and International Trade will be successful in promoting foreign tourism in the Colca Canyon region. This will change if local entrepreneurs can expand services for tourists. The same challenges face tourism development on the northwest shore of Lake Titicaca.

\section{The Northwest Shore of Lake Titicaca}

Long recognized as the world's highest navigable lake, Lake Titicaca (pronounced: ti-tee-KA-KA) sits at 3,860 meters $(12,421$ feet $)$ above sea level on the

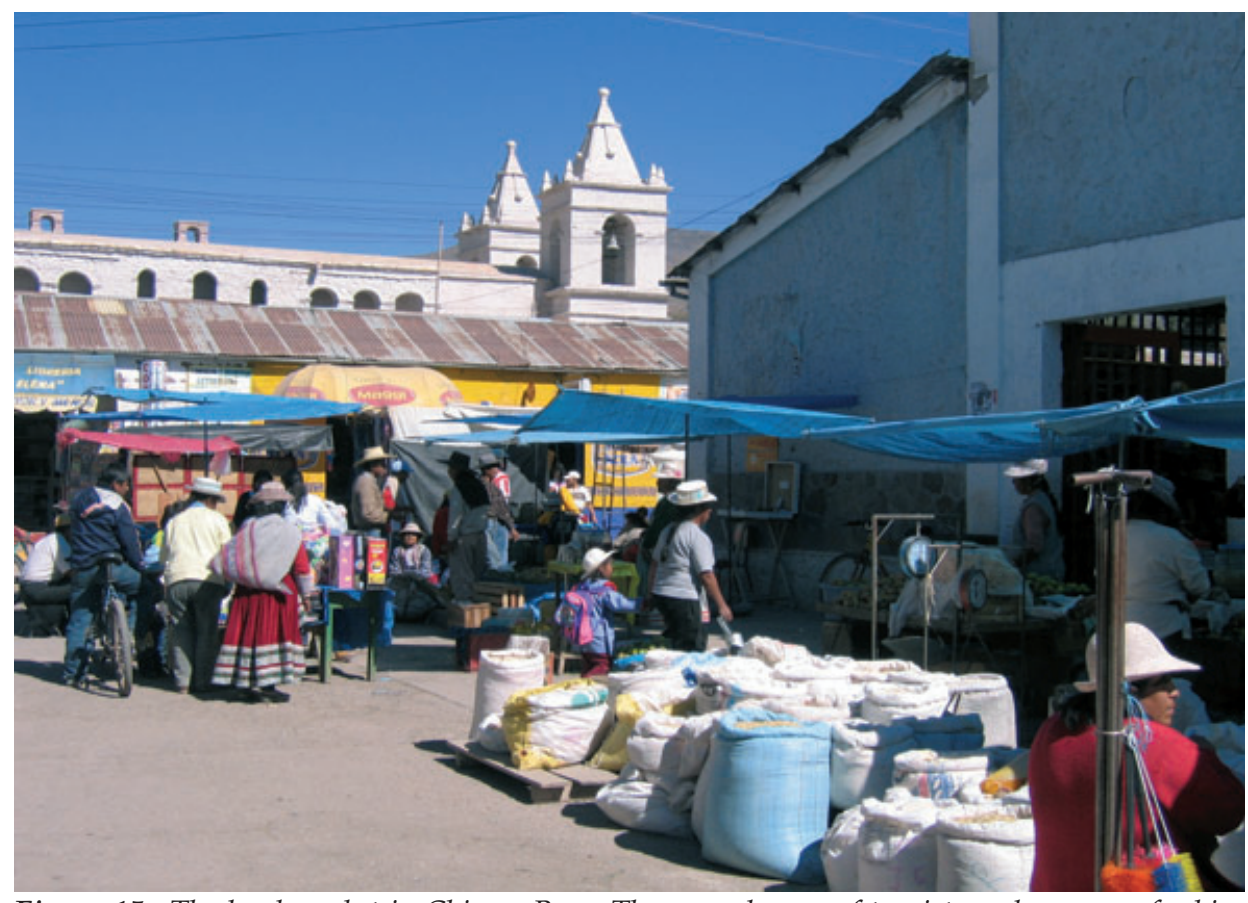

Figure 15: The local market in Chivay, Peru. The near absence of tourist goods was a refreshing change from the more heavily trafficked tourist sites in Peru. (Photo by Douglas A. Hurt, June 2006)

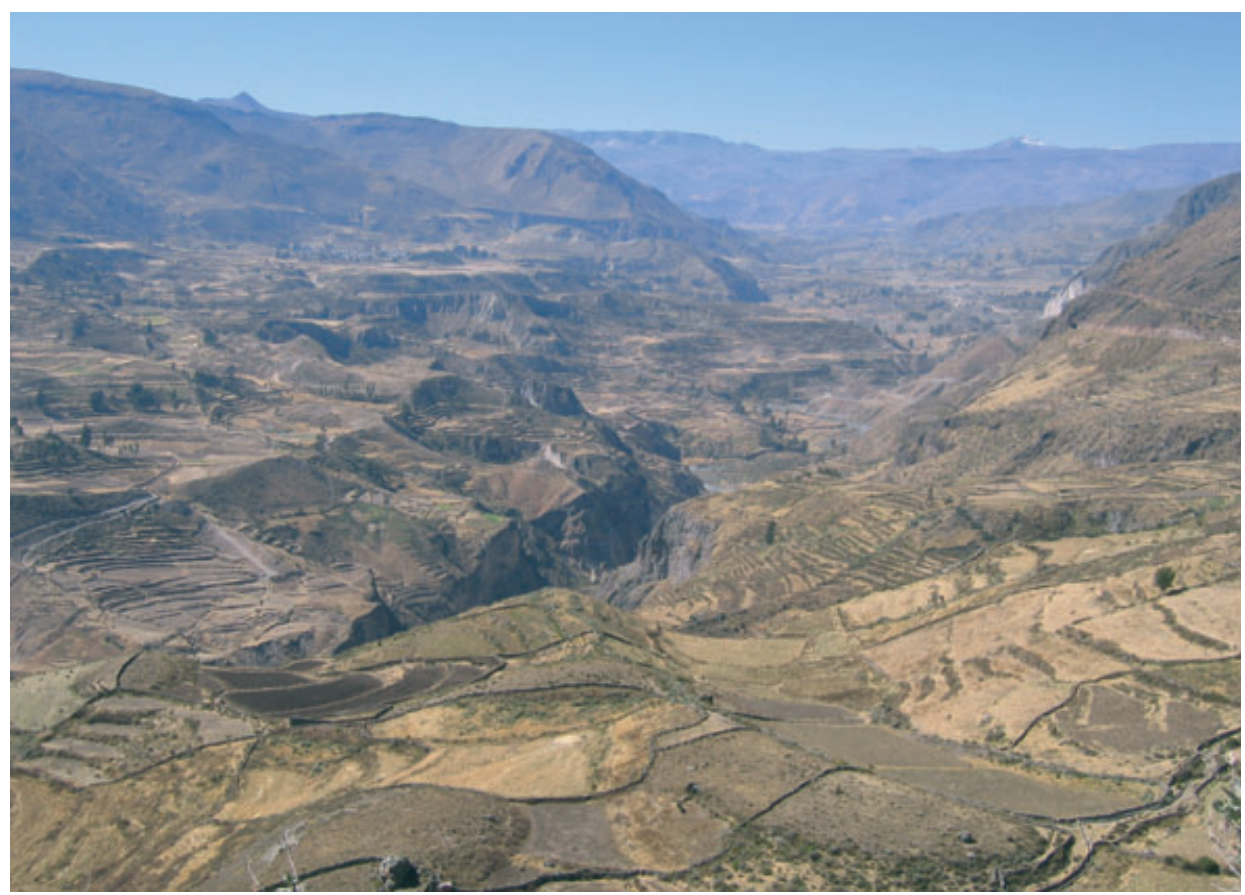

Figure 16: Aridity and ubiquitous terracing characterize the dramatic scene in the Colca Canyon. (Photo by Douglas A. Hurt, June 2006)

northern end of South America's extremely arid Altiplano. One legend suggests that the lake looks like a puma chasing a rabbit (McIntyre 1973). For the Inca, Lake Titicaca is one of the most significant places in the world because the Sun God allegedly commanded his son (Manco Capac) to ascend from its waters and start the Incan Empire (McIntyre 1973; Blacker 2008).
Abundant small villages dot the shore of the lake, but the principal population center is Puno. Founded by Viceroy Conde de Lemos in 1668 as a commercial center for surrounding silver mining activity, Puno's attention has always focused on Lake Titicaca. The lake is a reliable source of sustenance, income, and recreation. Puno also lies along the main transportation corridor between La Paz, Bolivia and 


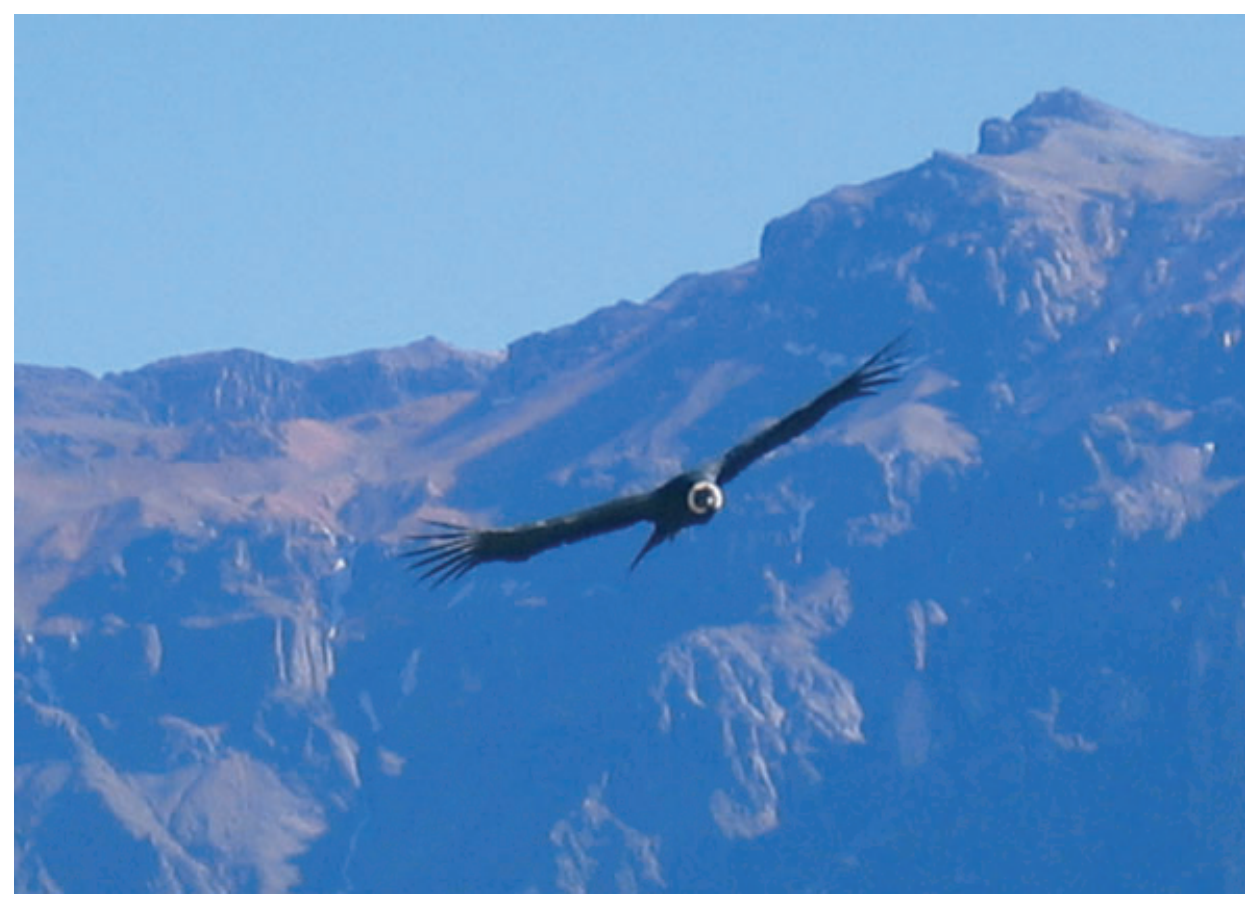

Figure 17: A graceful condor soaring on thermals thrills tourists at La Cruz del Condor. (Photo by Douglas A. Hurt, June 2006)
Lima, Peru. Despite its spectacular setting, Puno will not be mistaken for one of South America's most beautiful cities. Its earthtone buildings blend into the surrounding natural landscape giving the city an unassuming appearance (Figure 18). Local guides say that in the recent past Puno had the reputation as being a haven for drug and contraband smugglers who offered goods (especially gasoline and diesel fuel) to nearby residents of Bolivia at reduced prices. Moreover, on the outskirts of the city is Peru's highest maximum security prison where some of the country's most feared public enemies, including members of Sendero Luminoso (Shining Path), are incarcerated. The detention center's most famous guest, however, was former Peruvian President Alberto Fujimori.

Today, the city that laps up on the northwest shore of Lake Titicaca is making strides to change its unseemly reputation. Civic leaders are proud of the fact that

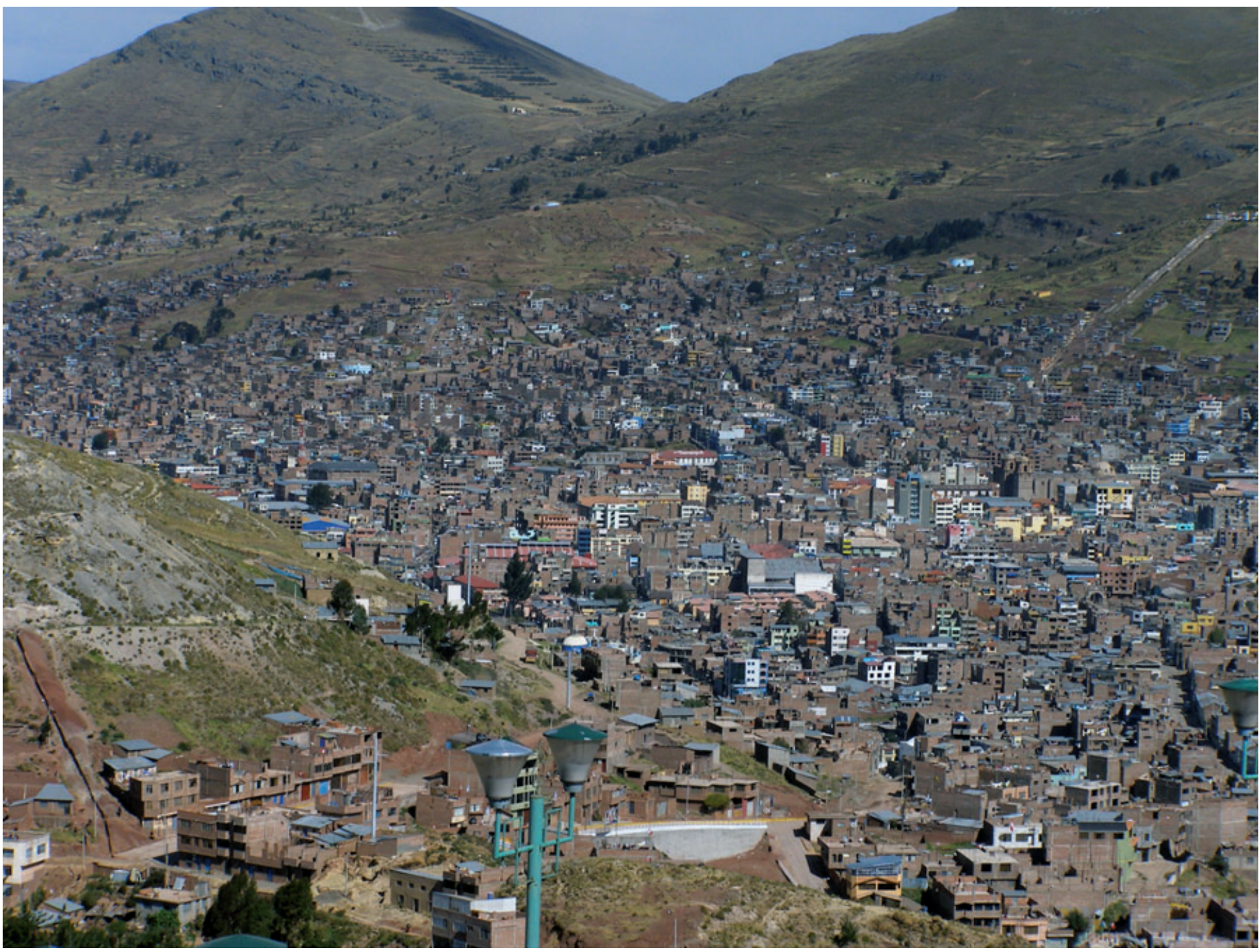

Figure 18: Puno, Peru. (Photo by Jeffrey Smith, May 2009) 
Puno is considered the folklore capital of Peru; its lively celebrations, beautiful dances, and colorful festivals are regarded as some of the best in the country (Blacker 2008).

Most international tourists who visit Puno and the Lake Titicaca region arrive by tour bus after a long day's ride from Cuzco. By the time they reach Puno they are typically exhausted and ready to retire for the night. What attracts them is the famous floating islands of the Uros people (Figures 19 and 20). For thousands of years the island's occupants have interlaced layers of tortora reeds to create 41 floating islands each inhabited by a small clan of families (Blacker 2008). Globalization and modernization are slowly reaching these isolated islands however. The younger Uros population prefers living in Puno where life is more exciting and there is a wider variety of employment opportunities. Plus, satellite TV and solar energy have made their way to the islands bringing about cultural change (Figure 21).

Lake Titicaca's other popular tourist destination is the Island of Taquile. Tourists load into motorboats and endure the three-to-four hour one-way trip to see an island purported to look similar to islands

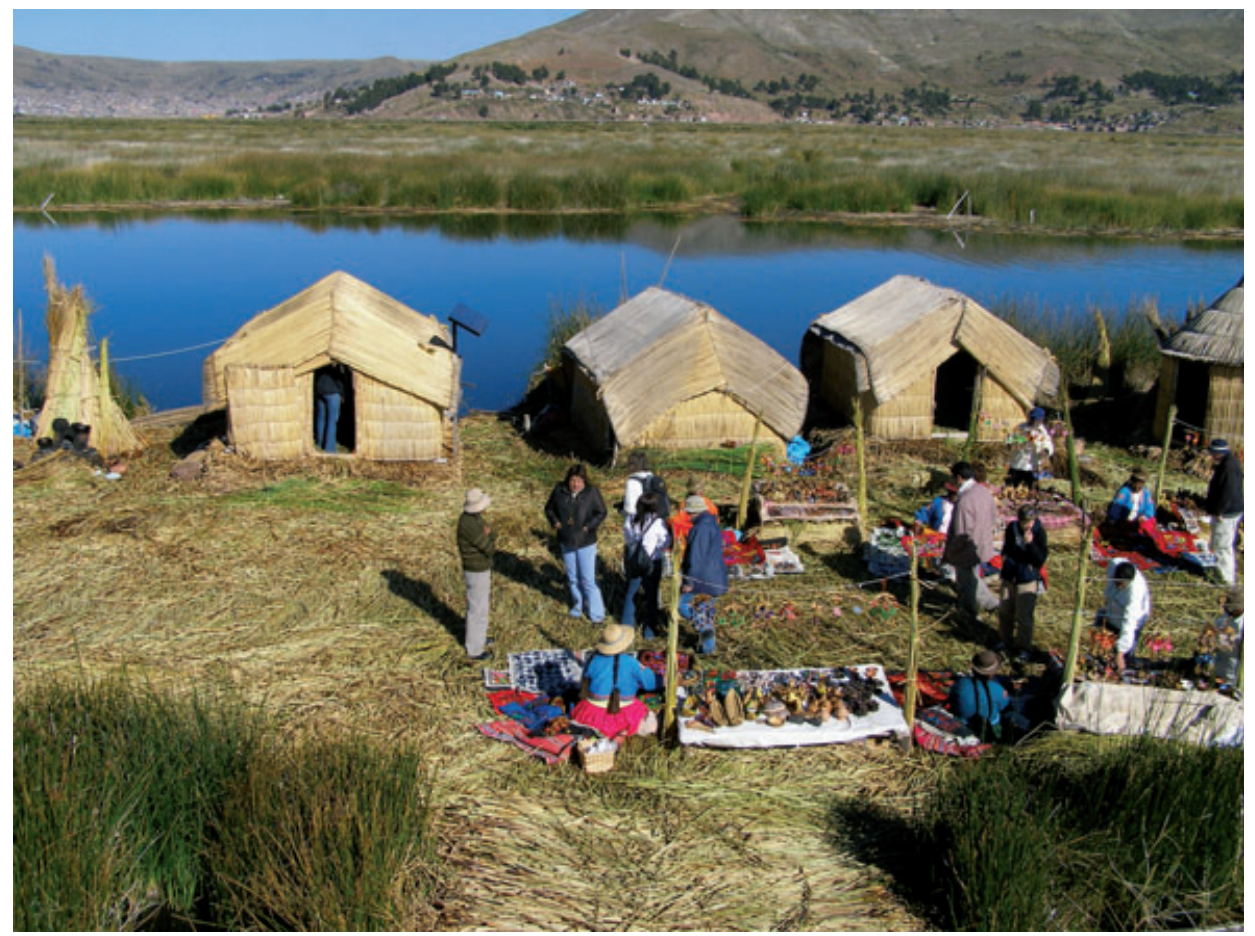

Figure 19: One of 41 floating islands on Lake Titicaca. (Photo by Jeffrey Smith, May 2009) found in Greece. By the time they return to Puno, however, they are once again exhausted from a long day on the water. Most people's itineraries have them departing Puno the next morning for points beyond. Sadly, few tourists spend the extra day becoming familiar with what Puno itself has to offer.

Over the past decade, the city of Puno has invested considerable time and money expanding its tourist infrastructure. On the surrounding hills are two miradores (overlooks) that offer spectacular vistas of Lake Titicaca's northern shore (Figure 22). We hired a taxi to drive the short distance up to the Puma overlook. The space offers a viewing platform at the base of the oversized Puma, a playground for children, and a covered picnic area. We were informed that the Condor overlook is just as attractive and well-developed. An additional overlook (Mirador Manco Capac) is located two blocks uphill (west) of the main plaza and cathedral. The views are much less spectacular, but its relative proximity to the downtown makes it appealing for visitors with tight schedules.

A second option for tourists visiting Puno is to walk along the pedestrian mall that connects to the charming Plaza de Armas. Because few tourists have "discovered" Puno, the four blocks sealed off to vehicles offer a mixture of stores for both visitors and locals alike. For tourists the space includes souvenir shops, a variety of restaurants, as well as bars and nightclubs. In the late afternoon, it is truly amazing to see how quickly people don sweaters as the sun goes down because at such a high elevation temperature drops quickly follow.

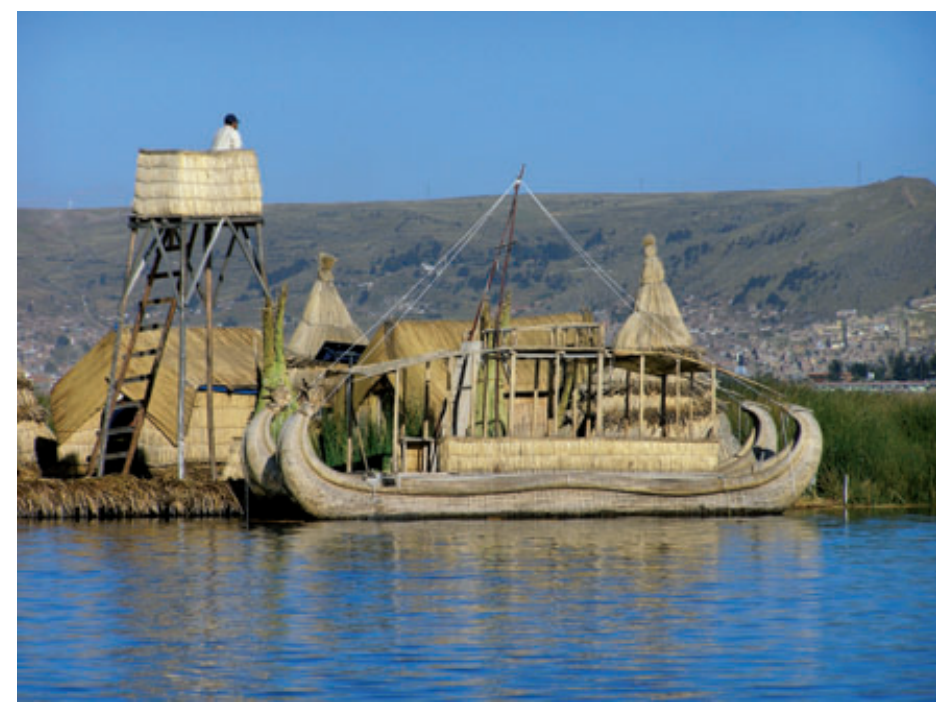

Figure 20: A lookout tower and reed boat on a floating island on Lake Titicaca. (Photo by Jeffrey Smith, May 2009)

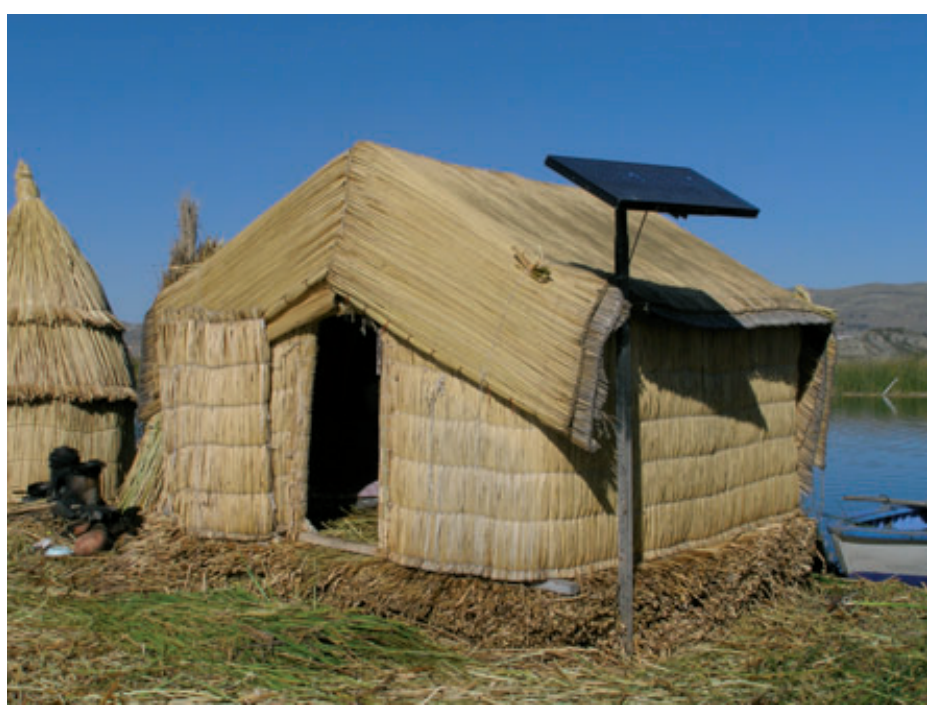

Figure 21: Note the private dwelling of the Uros people with a solar panel attached to the house. (Photo by Jeffrey Smith, May 2009) 


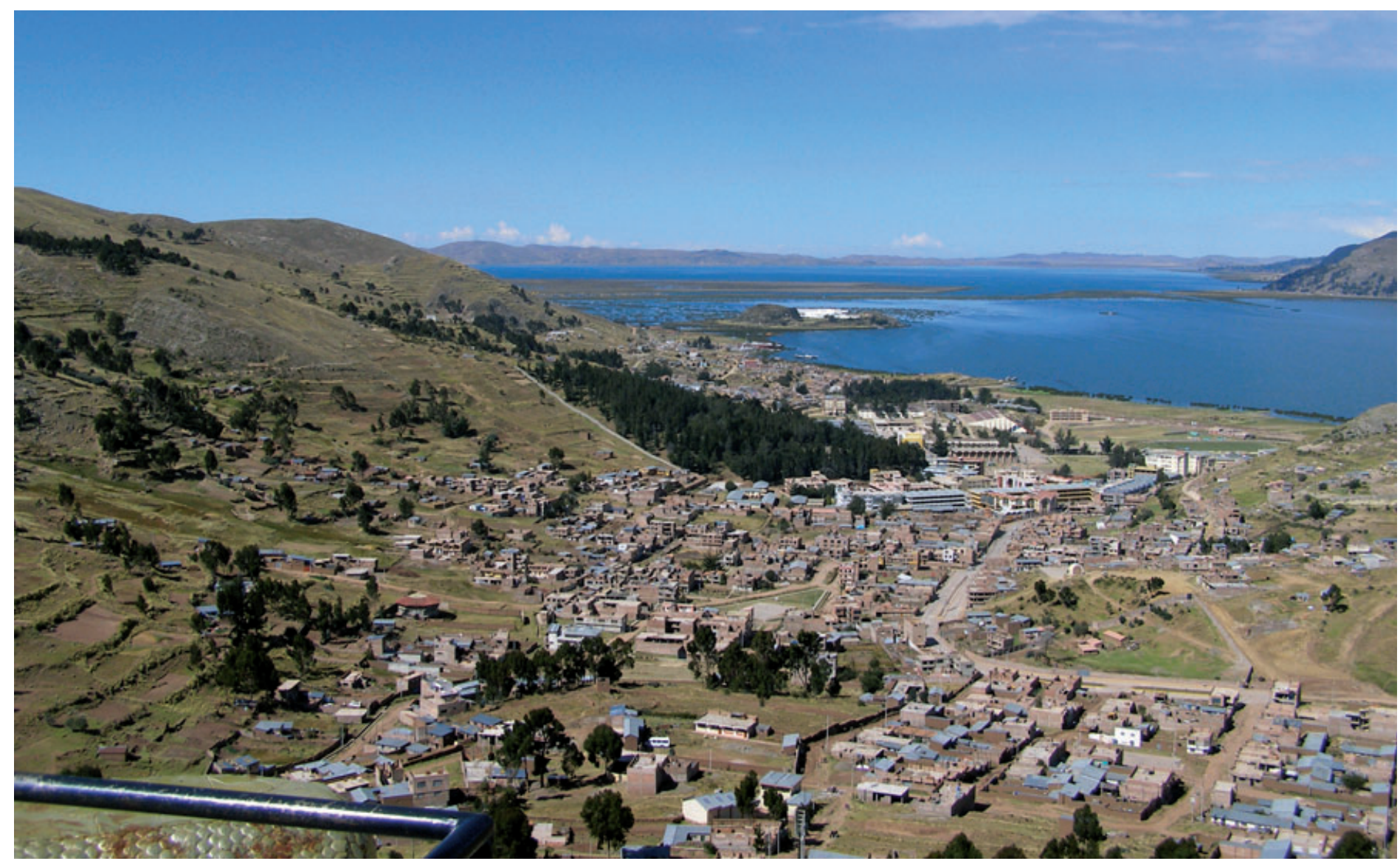

Figure 22: View of Lake Titicaca's northern shore from Puma Overlook in Puno. (Photo by Jeffrey Smith, May 2009)

Along the lakefront is a third space where city leaders have invested considerable government resources to improve Puno's appeal. The 900 meter ( 3,000 feet) concrete walkway from Puerto Lacustre (main boat dock) to the National University of the Altiplano offers visitors a chance to soak in the local surroundings (Figure 23). Between the walkway and the mainland is a small bay where visitors can enjoy paddle boats and other recreational watercraft. Although the space is dirty by U.S. standards, watching the boats ply the waters or taking in views of Lake Titicaca and the city is peaceful and relaxing. The space holds considerable tourism potential. Perhaps with a bit of luck or guidance from the Sun God and continued investment in tourism infrastructure, Puno also will catch the eye of international tourists.

\section{Conclusion}

The country of Peru has much to offer international tourists. From the ruins of ancient civilizations and beautiful colonial architecture to the latest in gastronomic and adventure tourism, Peru has it all. Unfortunately, most international tourists do not avail themselves of the breadth and

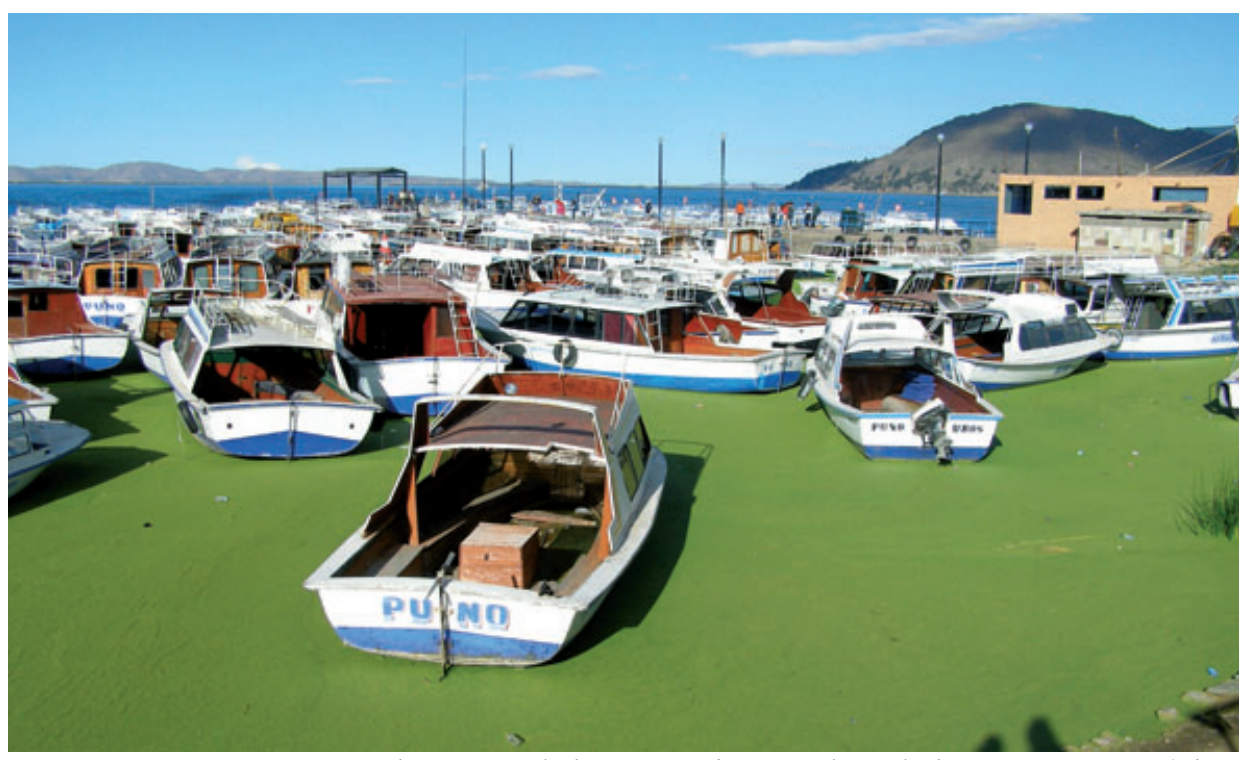

Figure 23: Boats sitting on algae-covered shore near the main boat dock in Puno, Peru. (Photo by Jeffrey Smith, May 2009)

instead, most spend their time in three locations; Lima, Cuzco, and Machu Picchu. These sites are worthy of their time, but as they succumb to the pressure of increasing tourism the government is trying to encourage visitors to consider other, equally impressive destinations. In this article we have identified three places that are worthy of consideration and are clearly on the cusp of tourism growth.

Among the three places we identify, the Sacred Valley holds the most promise for near-term tourist development. Already many international visitors pass through 
the area on their way to and from Machu Picchu. Once the local tourist infrastructure improves and word of the Sacred Valley spreads, will become an even more popular destination in its own right. The grandeur of the valley combined with the abundant Inca ruins gives the area potential as sky high as the surrounding mountains.

Puno on the northern shore of Lake Titicaca already entertains some international tourists visiting the area. The islands of Uros have become world famous, but unfortunately word has not spread about what Puno has to offer. Most visitors do not spend enough time during daylight hours to see the local beauty that residents of Puno take for granted. City officials are trying to change that by improving the local tourism infrastructure. It will most likely take some time before those investments pay dividends. Until then, tourists who are brave enough to be in the vanguard will reap the rewards.

Of the three locations we have pointed out, the Colca Canyon is the most geographically isolated and has the least developed tourism infrastructure. Like the other two locations, there is enough local appeal to attract international tourists to visit the area. The Colca Canyon is unique and exotic enough that it shows the greatest potential for rapid increase in international tourism.
Peppered throughout all three locations are lesser-known archaeological sites that are emerging as tourist attractions. If the Peruvian government is unwilling to limit the annual number of visitors inundating Machu Picchu, then perhaps by better promoting these other three locations they can take some of the pressure off Peru's most popular destination. Tourists who venture off the beaten path will find that these three locations are still relatively uncrowded. They may enjoy them as much as the more popular destinations. As time passes, the Sacred Valley, the Colca Canyon, and the northwest shore of Lake Titicaca will undoubtedly grow in popularity. They remain exciting destinations for tourists wishing to experience roads less traveled in Peru.

\section{References}

Blacker, M. 2008. Eyewitness Travel: Peru. London: Dorling Kindersley Limited.

Divino, J. A. and M. McAleer. 2009. Modelling and Forecasting Daily International Mass Tourism to Peru. Tourism Management (online discussion paper). <http:/ / eprints.ucm.es/8696/1/0915. pdf $>$.

Economist. 2010. Ruined: Making Do Without Machu Picchu. 13 February, p. 42.
McIntyre, L. 1973. The Lost Empire of the Incas. National Geographic 144(6): 729786.

O'Hare, G. and H. Barrett. 1999. Regional Inequalities in the Peruvian Tourist Industry. The Geographical Journal 165(1): 47-61.

Peru Tourism Bureau. 2010. The Colca Valley. <http://www.visitperu.com/ arequipa.htm $>$.

Ugarte, J. and L. Pacheco. 2001. Integrating Biodiversity into the Tourism Sector: Peru Country Case Study. Arequipa, Peru: Asociación Especializada para el Desarrollo Sostensible Aedes. <http:// www.unep.org/bpsp/Tourism/Case Stud ies(pdf)/PERU (Tourism).pdf>.

UNEP. 2008. Historic Sanctuary of Machu Picchu Peru. United Nations Environment Programme World Conservation Monitoring Centre, October. <http:// www.unep-wcmc.org/sites/wh/pdf/Machu Picchu.pdf $>$.

Vecchio, R. 2010. INC says Machu Picchu Entrance Tickets Will Be Rationed to Avoid Tourist Hoards When Rail Service Resumes. Andean Air Mail and Peruvian Times, 30 March. <http:/ / www. peruviantimes.com/inc-says-machu-picchu entrance-tickets-will-be-rationed-to-avoid tourist-hoards-when-rail-service-resumes / 305440>. 